ЗОЈА С. КАРАНОВЙ ${ }^{*}$

Филозофски факултет

Универзитет у Новом Саду
Оригинални научни рад

Примљен: 17.09.2021.

Прихваћен: 08.11.2021.

\title{
СВАТОВСКИ ВЕНАЦ И ПЕСМА У ОБРЕДНОЈ ПРАКСИ У СЕЛИМА ОКО БЕЛОГ ТИМОКА (заборављена традиција)
}

\begin{abstract}
У раду се истражује сегмент традиционалних свадбених обичаја који се везују за обредне и магијске радње и песме које су певане око вијења венца, на основу грађе сакупљене 1997. и 1998. године у српским селима око Белог Тимока, као и ранијих бележења одговарајућих радњи из суседних области. На основу тога сачињена је идеалтипска (ре)конструкција поменуте радње која је обављана ујутру, уочи свадбе, на дрвљанику код момкове куће, где су девојке, певајући, плеле венац а затим га, заједно са кошуљом коју је момку даровала будућа невеста, у ситу, стављале свекрви на главу, где су га сватови даривали. У датом окружењу аналазирају се песме и испитује њихова релација према аналогним манифестацијама обреда и испитују се њихове везе, значења и функције на испитиваном терену и у српској руралној култури уопште. Анализе показују да плетење сватовског венца, као и сви други ритуали, представља својеврстан културолошки текст који се испољава кроз одређене акције и вербализације, да се одвија у фиксираном време-простору у којем их обављају учесници обреда. И све је ту повезано и семиотички маркирано образујући својеврсну „паралелну" реалност која је у функцији стварања нових односа и веза у заједници, што је неопходно имати на уму како би се разумела природа комуникације која се остварује приликом склапања брака.
\end{abstract}

Кључне речи: српска традицијска култура, теренски рад, села око Белог Тимока, сватовска обредност, венац, песма.

Познато је да је венац међу Словенима и Србима симболички предмет прве врсте и, сходно томе, коришћен је у ритуалној пракси везаној за годишње обичаје и обреде животног циклуса. ${ }^{1}$ Магијска заштита његовог облика, допуњена симболиком биља које се у њега уплиће, обезбедила му је високо место и

"zojanko@stcable.net

${ }^{1}$ Функције венца су различите: заштита куће, амбара, стоке, поља, плете се за добар род и сточно благостање, заштите од непогода, нечисте силе, веровало се да има исцелитељске моћи, служио је у лустративне намене (Петровић 1998: 86-89; Гура 1995: 322-324). 
у свадбеним ритуалима (в. Петровић 1998: 86-89; Гура 1995: 321-325) - један је од најважних предмета у свадби. Венац је превасходно атрубут девојке и девичанства, предмет који се везује за младу, на венчању га носи млада, понекад младожења, али га могу носити и други учесници обреда па се, сходно томе, уобичајено и плете уочи свадбе (Петровић 1998: 86-89; Гура 1995: 322-324). У овом раду истражује се поменути сегмент свадбених обичаја у селима око Белог Тимока ${ }^{2}$ и у суседним областима, који се везују за одговарајуће обредне и магијске радње.

О плетењу венца на испитиваном терену Анка Цветковић из Кожеља је, између осталог, саопштила: „У недељу певице вију венац рано ујутру на дрвник.”’ И Божика Живковић (Витковац) поменула је његово плетење овако: „тад су певице, док вију венац јеле кравај, он се подели на сви”. О вијењу венца у тимочкој области сведочи још Милан Ђ. Милићевић у другој половини деветнаестог века, речима: „У суботу се скупе четири девојке; узму пуно сито цвећа и младожењину кошуљу, попну се на дрвљаник и ту вију венац и певају"(Милићевић 1876: 866). И Маринко Станојевић у својим белешкама с почетка прошлог века, помиње на сличан начин обред плетења венца „за младу невесту”, у суботу, у Новом Кориту (Станојевић 1937: 84). А у Врбици је, како каже, рано ујутро, младожења, заједно с певицама, ишао да зову девојке да вију венац на дрвљанику његове куће, кад би једна од њих позивала девојке овако: „Ајдете, друшће, дојдете да плетемо венац” (Станојевић 1929: 45-46; 1937: 90). Свекрва тада „метне у сито кошуљу, коју је млада - невеста послала младожењи" (Станојевић 1929: 46). А свака од позваних девојака би донела неки цвет (босиљак, големо цвеће,

\footnotetext{
${ }^{2}$ Ауторка овог рада боравила је, заједно са Весном Ђукић, на терену у делу Тимочке Крајине, у селима око Белог Тимока: Боровац, Бучје, Валевац, Врбица, Витковац, Дебелица, Дреновац, Јаковац, Јелашница, Кожељ, Мариновац, Мали Извор, Ново Корито, Ошљане, Петруша, Потркање, Равна, Селачко, Трновац, у неколико наврата 1997. и 1998, кад је забележено преко 250 српских народних песама, с фрагментарним подацима о контексту, односно месту, времену и начину њиховог извођења, као и извођачима и осталим пропратним елементима (кад је то било могућно). И ова грађа припрема се за штампу. Напомињем да се рад на терену одвијао без финансијске потпоре било које државне институције или невладине организације, као и без претходне припреме везане за сондирање терена и у вези с тим помоћи локалних власти. Касније, 2014, 2015. и 2016, ауторка је радила на истом терену с групом колега и студената чије истраживање је организовала и предводила, тада уз симболичну финансијску помоћ Филозофског факлтета у Новом Саду и потпору Завичајног музеја у Књажевцу, који нам је бесплатно уступио смештај у Архео-етно парку Равна. Намера је била да се, поред осталог, провере већ сачињени записи и, евентуално, пронађу нове, још увек живе песме. Показало се, међутим, да већина ранијих казивачица више није међу нама, док се оне с којима су разговори у новије време вођени углавном нису сећале песама, мада су и даље памтиле фрагменте некадашњих обреда у оквиру којих су оне извођене. Рад је обављан методом случајног одабира саговорника. Разговори су у првом наврату снимани касетофоном, касније диктафоном, кад је било могуће, и ти снимци су у поседу истраживача. Разговори су иначе вођени уз пуну усмену сагласност казивача, на чему им захваљујемо. Такође захваљујем колегиницама и студентима на уложеном труду и оживљавању сећања казивача.

${ }^{3}$ Место одређено за дрва. Сматра се граничним простором, нечисто место (Детелић 1992: 128) које у предсвадбеним ритуалима симболизује прелазни период.
} 
стратор, страторин $\left.{ }^{4} . ..\right)$ и стављала га у сито, и свака је морала да уплете у њега барем једну гранчицу. Кад је венац исплетен „младожења опали из пиштоља” (Станојевић 1937: 90). То је иначе мали венац који млада носи у недрима или у „хаљинама венчаним” (марамици), на венчање, и сматрало се да је лековит (Станојевић 1929 45-46). ${ }^{5}$ И Оливера Васић је 1996/7. године (Васић 1999: 268) записала да су девојке у поменутој прилици плеле венац на дрвљанику, као и да је свака девојка понешто у њега додавала, венац се, затим, како такође додаје, стављао у сито с „прстеном, перорезом и кошуљом и доносио свекрви”. Она је седала на праг куће, а певице би јој стављале сито на главу, док би сватови који би тада почели да долазе, бацали новчић у сито и говорили: „Честит ти венчић”; њега је невеста на венчање носила у марамици (Васић 1999: 268). Девојке су увече истог дана виле и венац младој за главу, од вештачког цвећа (в. Станојевић 1929: 46). Правио се и венчић за свекрву, те велики отворени венац, „за вратнице” (Васић 1999: 269). „Тај венац се закива на капију. Било и прошло. Заборили смо. Не мог' се сетим, ич", саопштила је на терену баба Зора из Селачка (1998). А певало се, како се каже, све док венац извију (Станојевић 1929: 45-46; 1937: 90).

У Белом Тимоку, на терену, забележиле смо три песме које говоре о плетењу венца. Прва гласи овако:

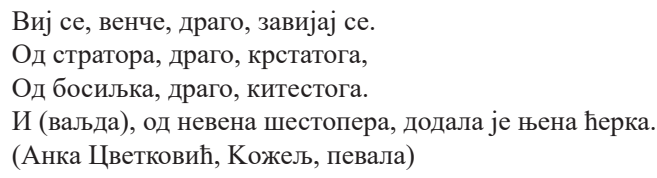

Ова песма - на простору Тимока и у суседним областима евидентирана у неколико блиских варијаната ${ }^{6}$ (као Рајковић Кожељац 1963: 73; Рајковић Кожељац 1972: бр. 32) које се међусобно објашњавају и допуњују. А садржином и временом извођења у корелацији је с одговарајућим ритуалним поступцима и њено певање временски се поклапа с обредном акцијом коју на својеврстан начин и коментарише. ${ }^{7}$ Другим речима, евидентно је дублирање акционалног и вербално-поетског кода, односно веза обредне радње и поезије ту је непрекинута и у тренутку плетења не може се успоставити граница између акције и вербализације; оне једна другу сустижу у својеврсној појавности обредног синкре-

\footnotetext{
${ }^{4}$ Могуће траторина (страторина), Centaurea (в. Шулек 1879: 408; Симоновић 1959: 674), биљке из породице различка.

${ }^{5}$ Ово је мајушни венац који млада носи у недрима током венчања, употребљава се и као лек од различитих болести. Од куповног цвећа праве венац који ће млада носити на глави (Станојевић 1929: 45-46).

${ }^{6}$ Види Прилог уз овај рад, где су наведене песме које су обухваћене анализама у овом раду. То су уједно и све достпуне песме, мада је могуће да су неки записи ауторки промакли.

${ }^{7}$ Истовремено је место и време - темпорални и локативни кодови. Општење у обреду свадбе иначе се остварује помоћу свадбених песама, одговарајућих текстова и ритуалних радњи (в. ГУРА 2006: 273), као и осталих пратећих елемената (о томе Толстој 1995: 141-143).
} 
тизма, (релативизујући уједно проток изванобредног времена од којег се ритуал одмиче ${ }^{8}$, што указује на велику важност извођења песме у датим оквирима.

Песма се отвара фиктивним обраћањем безличног наратора венцу, стихом: „Виј се, венче, драго, завијај се”, при чему се контакт невидљивог говорника и ритуалног објекта у настајању успоставља императивном формом одговарајућих глагола. ${ }^{9}$ Овај прастари облик комуникације - оријентисан на примаоца (императив плус вокатив - односно повезивање наредбе с потенцијалним изврштељем (објактом/сујектом), венцем (в. Јакобсон 1966: 292), формула ${ }^{10}$ је којом се иначе у магији позива на деловање, овде на самообликовање магијског предмета - такође је „гаранција” велике старине стихова, при чему се актери медијатори (девојке) и, иако присутни песмом не помињу, све у функцији концентрације на венац. Ипак, поступност и трајност која је за магију неопходна остварује се понављањем глагола сличног звучања и значења: виј се, завијај се (правити нешто савијањем и мотањем). Понављање се реализује и наредним стиховима, набрајањима цветних реквизита: „Од стратора, драго, крстатога/ Од босиљка, драго, китестога/ И (ваљда) од невена шестопера", где је високо мотивисано и коришћење партитивног генитива, на почетку сваког од три формулативна стиха овако: „од босиљка”, „од стратора”, „од невена”, које упућује на биљке издвојене из своје природне средине, како би у венцу задобиле нова симболичка значења. Управо тим цветовима и цветним стиховима од речи интензивирају се магијски потенцијали тратора, босиљка, невена - будући да по веровањима све три биљке имају снажне заштитне и лустративне моћи. Цветови се иначе нижу један за другим, симулирајући поступност радње уплитања, управо онако како је и било неопходно да свака девојка у венац дода понеки цвет, што даље успорава процес нужан за успешност магијског деловања. А наизменично уплитање и успоравање радње остварује се и низом синтаксичко-семантичких паралелизама који се, даље, на крају сваког од завршних стихова варирају различитим атрибутским особинама флоралних реквизита - стратор је крстати ${ }^{11}$,

\footnotetext{
${ }^{8}$ Обредно време има особине другачије од уобичајеног тока времена. Оно може бити развучено, или је спресовано (Тарнер 1986: 41-43).

${ }^{9}$ Овај облик, како је запазио још Јакобсон, представља прастару форму комуникације, као у басмама (1966: 292) и потврђује архаичност исказа.

${ }^{10}$ Језик усмене песничке традиције је у својој основи формулативан, односно гради се на устаљеним и наслеђеним средствима изражавања, која се у науци именују и дефинишу разнолико. При томе, формула не представља само речи и скупине речи које се редовно користе „под истим метричким условима да изрази[е] дату основну идеју” (Parry), (Лорд 1990: 21), већ обухвата сваку врсту по овој матрици грађених понављања. Имајући на уму оно што је речено, може се рећи и да je: „Формула [...] средиште семантичке гравитације на које се одлажу духовне вредности читавих епоха (Формула - это иентр семантической гравитации, на который оседают духовные ценности uельых эпох (Маљцев 1989: 87). И, сходно томе, поетика текста и поетика традиције садрже дубинска значења (текст активно комуницира с традицијом) која се сучељавају у формули (Маљцев 1989: 85). И још: „Формула - то је облик текста, и компонента његовог садржаја, и „кретања” ка садржају, пут од „облика” ка „смислу”” (Формула — это и форма текста, и компонент его содержания, и способ „движения” к содержанию, путь от „, формы” к ,смыслу”) (Маљцев 1989: 54).

${ }^{11}$ Основни смисао овог придева изводи из именице крст, који има знак крста (в. Караџић 1852). Ова атрибуција везује се и за биљке чије лишће личи на крст: кристати копитьак (Anemone
} 
босиљак је китести ${ }^{12}$, невен шестопер ${ }^{13}$ ), подржавајући разноликост биљака на квалитативном, визуелном и сваком другом плану, чијем се шаренилу, на крају кад је венац довршен ${ }^{14}$, сви радују. Магијске потенцијале радње појачава овде и „развучени” десетерац читавог катрена који се гради уз помоћ додавања, речи драго која се понавља унутар сваког од „цветних стихова”, увек након цезуре (односно њених ритмичко-семантичких потенцијала), где се могуће ради о прилошкој усмерености на дату атрибуцију, у значењу драго крстатога, овако: „Од стратора драго крстатога"/. Од босиљка драго китестога"..., мада је вероватније реч о вокативу придевске именице. Њоме девојке, плетући венац, дозивају везу будућих младенаца и истовремено се обраћају својим драганима, па би стихови изгледали овако: „Од стратора, драго, крстатога”, / Од босиљка, драго, китестога” (о томе в. и Карановић 2021: 543-558). Ово даље потврђују стихови: „Од стратора, драгу, крстатога,/ Од невена, драгу, шестопера" (Рајковић Кожељац 1963: 73), у варијанти у којој се, дативским обликом именице асоцира онај коме је венац намењен. А пример стихова „Ви се венче, драго ле,/ За девојку, драго ле” (Рајковић Кожељац 1978: бр. 164) на крају и демистификује стварни ритуални субјекат којем се он намењује. Постепеност његовог плетења и предавања девојци исказана је и стихом: „Ви се, венче, ми те довијамо”. А у наставку, у овој песми венац се преноси од руке до руке - од кумова, до старојка, и до девојке, што је исказано елиптичним стиховима: „Ти ћеш, венче, код кумов д’ идеш,/ Од

hepatica), крстата трава (Pastinaca sativa Psilvestris), крстати слез (Abutilon; Avicennae), крстато игличе (Primula veris). Атрибут се везује се и за дрво с урезаним крстом, запис (Жугић 2013:108-109). Крстати у песми може бити и босиљак:

$$
\begin{aligned}
& \text { Иконице, госпођо, } \\
& \text { Што ти двори миришу } \\
& \text { На бел-црвен трендафил, } \\
& \text { И крстати босиљак. } \\
& \text { (Златановић 1994: 80-81) }
\end{aligned}
$$

Али се везује и за друге биљке, као у песми коју смо забележиле у Врбици од Милице Петковић, 1998:

$$
\begin{aligned}
& \text { Да ћитимо пребела зборника } \\
& \text { Од босиљка, драго, крстатога, } \\
& \text { Од стратора, драго, крстатога } \\
& \text { И од смиља, драго, крстатога. }
\end{aligned}
$$

О томе види и Карановић 2021: 543-558.

${ }^{12}$ Овај атрибут уз босиљак помиње већ Вук у свом речнику (Караџић 1852), а у песмама из мотивске групе везује се нпр. уз смиље, у стиховима: „И од смиља, драго, китњастога/ћитатога” (Станојевић 1896 (ркп.) бр. 121; Станојевић 1937: 90).

${ }^{13}$ Шестопер/шестореден, цвет са шест латица у шест слојева, нпр. у стиховима: Ој невене шестореде,/Шестореде, шестопере (Васиљевић 1960: бр. 307); Ој невене шестопере,/ Што ти беше те увене/ те цвилеше (Димитријевић 1987: 42); Мој невене шестопере,/ А што теби перје вене (Станковић 2009: 87).

${ }^{14}$ Манипулација биљем је сложен процес у којем се активирају различита знања која углавном припадају женама, често и вилама (Ђорђевић 1953: 103-104; Ђорђевић 1958: 573; Чајкановић 1994б: 178). 
кумове, венче, до старојку,/ Од старојку, венче, до девојку.” (Васић 1999: 268, Врбица, Ново Корито), где доминирају понављања именских речи - које садрже номинације и функције часника, док се глаголским обликом „ублаженог” императива „д’ идеш” истиче безусловност међусобног везивања кума и старог свата с младом, преко венца који се, уз то, и персонификује и задобија функцију свата који иде по девојку - везивање и јесте његова основна функција. Жељени ефекат се, дакле, остварује у међусобном односу ритуалне радње, објекта и одговарајућих песничких текстова које их овде прате и подржавају. ${ }^{15}$

Забележене су и две варијанте песме које антиципирају у литератури забележен обред ношења и предавања венца будућој невести - који јој се он даје уз венчану хаљину. Прва је, запис начињен „испод Ртња у долини Црне реке” и извођена је док се венац вије у петак у зору, „код момкове куће за младу” овако:

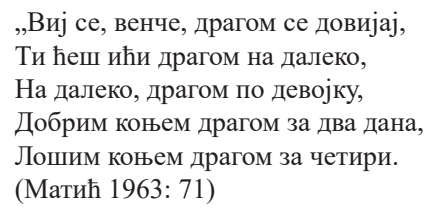

И у њој се значај венца валоризује такође персонификацијом: „Ти ћеш ићи драгом на далеко,/ На далеко, драгом по девојку”. А раздаљина се и даље мери бројем дана који су потребни коњима да до девојке дођу. И у доцнијем запису (Тимочка Крајина), стихови који се такође односе на простор-време ношења венца (потврђујући речено), понављају поменуту радњу овако:

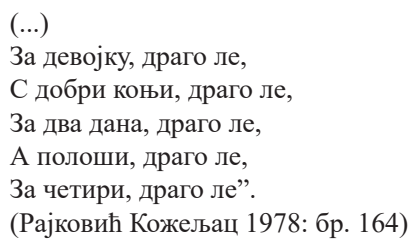

И овим уједно стихови уводе у мотивски круг песама удаја на далеко.

Развијенији варијантни записи, даље, остављају простора за стварне актере ритуала, на пример стихом „Виле моме драгу зелен венац” и њихово уобичајено императивно обраћање рукотворини, да се сама прави. Магију деловања ту појачавају, нагомилавајући се, различити облици глагола с основом ви(mu) и $c a(в u)$ јати, као у примеру: „Ем га виле, ем му говориле:/ 'Виј се венче, виј се, савијај се"” (Рајковић Кожељац 1972: бр. 32).

Вијење венца предмет је и стихова песме коју смо забележиле на терену, у селу Ошљане, од Савке Савић, у којој се као вршилац обредне радње истиче појединац који намењује венце момку и девојци стиховима:

${ }^{15}$ О томе више види Гура 2006: 272. 
Вила Јана, драго, зелен венац,

Па извила два зелена венца,

Један момку, један на девојку.

Њен ранији варијантни запис у бележењу Маринка Станојевића, наговештава и име женика, стиховима: „Виј се венче, драго, завијај се,/ Да те носи, драго, Д... јунак,/ Д... јунак, драго, и добра девојка" (Станојевић 1896 (ркп.) бр. 121). А довођење ове песме у везу с конкретном свадбом манифестује се још директније укључивањем пуног имена, у стиховима истог записивача: „Да те носи, драго, Давњан јунак,/ Давњан јунак, драго, добра девојћа" (Станојевић 1929: 46), чиме се песма доводи у непосредну везу с одговарајућим поступцима и значењем се поклапа с датом обредном акцијом коју на својеврстан начин коментарише, што је такође прастари начин комуникације учесника у обреду.

У селу Ошљане од Росе Николић записале смо и стихове песме која је такође извођена код плетења венца, а у којој девојка венце које израђује намењује неком из своје најближе околине - за здравље куму, свекру и младима, у стиховима:

$$
\begin{aligned}
& \text { Вила Јана, драгу, зелен венац, } \\
& \text { Па извила три зелени венца: } \\
& \text { Један венац за кумово здравље, } \\
& \text { Други вила за свекрово здравље, } \\
& \text { Трећи вила младима за здравље. }
\end{aligned}
$$

Ова некад популарна песма (в. нпр. Караџић 1824: бр. 128; 1841: бр. 330, $332,333)$, исказима: „за кумово здравље”, „за свекрово здравље” , „младима за здравље", рефлектује и илуструје веровање у исцелитељске моћи сватовског венца (о томе у Тимоку в. Станојевић 1929: 46). А варирајући положај предлога, у трећем исказу давањем примата ритуалним субјектима „младима” наговештена је не само посебност њихове социјалне позиције, већ и изузетност потребе њихове заштите, будући да се они све време свадбе налазе у опасном простору прелазне зоне. Аналогна је, затим, радња с венцима који су такође намењивани часницима и младенцима, у мелодијском запису песме забележене у селу Васиљ, у стиховима:

\footnotetext{
Што је венац од жутога цвећа,

То је венац за милога кума,

Што је венац од белог босиљка,

То је венац за старога свата.

Што је венац од жутога смиља,

То је венац за младу и младог.

(Васић 1999: 269)
}

И у обе песме куму и свекру/старом свату припада по један венац, док је младенцима намењен један заједнички, којим се они симболички повезују, истовремено асоцирајући одговарајуће фазе ритуала. 
О важности обредног венца који плетиље/плетиља неком намењује сведочи још песнички запис у Рањинином зборнику из 16 века ${ }^{16}$ (в. и Крњевић 1986: 33-34), у стиховима:

Vila je moma tri vjenačca; pelinak

bere, ružicu prosiplje.

Jedan je vila od tratorka pelinak

bere, ružicu prosiplje.

Drugi je vila od bosioka; pelinak

bere, ružicu prosiplje.

Tretji je vila od ružice; pelinak

bere, ružicu prosiplje.

Koji je vila od tratorka; pelinak

bere, ružicu prosiplje, -

taj mi [je] bracu darovala; pelinak

bere, ružicu prosiplje.

Koji je vila od bosioka,

taj mi je sama pronosila; pelinak

bere, ružicu prosiplje.

Koji je vila od ružice,

taj mi je hrabru darovala; pelinak

bere, ružicu prosiplje.

(Решетар 1937: бр. 635)

Аналогију међу наведеним записима из Тимока с песмом из Рањининог зборника, поред актера и њене мотивско-садржинске димензије, успостављају биљни реквизити који се уплићу у венац - босиљак, траторак (Acantus mollis) и ружица (Rosa Cannina). Босиљак је, наравно, биљка посведочена свуда, у сватоском венцу из Тимока и шире. А ружа и тратор, сведочећи о распрострањености традиције аналогних веровања и певања, присутни су такође код Вука Караџића (1841: бр. 332, 333) $)^{17}$ и доцније.

${ }^{16}$ Док већина истраживача сматра да је ово песма „на народну”, види код: Лајшић 2009: 171190, Владан Недић се залаже за став по којем је ово у основи народна песме (Недић 1967: 31-41).

${ }^{17}$ Иако су тратор и траторак (матруна познат и као примог), две различите биљке, повезује их сличан назив, звучање и истоветан облик деминутива речи тратор, па се могуће и мисли на исту биљку. У вези с тим и помен траторка, под називом - примог, у свадбено-погребном венцу у спеву „Вила Словинка” (1614), Јураја Бараковића, у одговору виле на питање мајке Маргарите где јој је син, не искључује такву могућност. Стихови гласе овако:

Јер када ми он дојде у Приморје валовито,

Оно младо дите;

На њега се намири липа Цвите Приморкиња,

На то младо дите;

Она венац вијаше од примога виловита,

Млада Приморкиња;

Онди ми се они биху очицами сагледали,

Млади и гиздави;

Очицама сагледали а срдашци саљубили, Млади и гиздави.

Бише ми га липа Цвите оним венцем окрунила, 
Све биљке које се према песмама из Тимока уплићу у сватовски венац иначе имају висок сакрални статус у традицији српског народа и некада су служиле као јака заштитна и лустративна средства. Тратор, којег у Тимоку зову стратор (Amaranthus), у словенским културама је заиста коришћен за израду свадбеног венца (в. Гура 1995: 322); налази се такође у венцу Вукове песме (Караџић 1841: бр. 333) ${ }^{18}$, коју као део игре цвећем у Требињу помиње и Врчевић (Врчевић 1989: $42)^{19}$, а и у предсвадбеној и свадбеној ритуалности на терену имао је истакнуто место (Станојевић 1929: 36, 42-43. 45-46, 48) - већ на огледима, кад девојка заврши с даривањем момкових, она сваком госту даје киту цвећа у којој се налазио тратор и босиљак. А и кад зову сватове (у петак), око буклијина грлића налазио се венац од цвећа, у којем је такође било тратора (Станојевић 1929: 43). Присуство тратора у свадби, иако је сећање на њега у етнографској литератури оскудно $^{20}$, могуће је утемељено у стварним особинама његовог цвета који дуго остаје

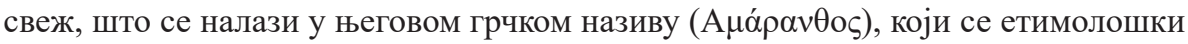
везује за идеју „оног који стоји”, „који траје (в. Софрић 1912: 211).” Босиљак (Ocimum basilicum) је, супротно, у култури Срба и Словена сакрална биљка прве врсте, као и важан реквизит заштите код прављења свадбених венаца (в. Чајкановић 1935: 3-10; Чајкановић 1994а: 41-42 ) - а њиме се у ритуалима око склапања брака ките и други предмети и људи, (в. Чајкановић 1994а: 40-41; Усачова

\footnotetext{
Оно младо дите;

Да се нигдар никадаре к теби мајци не заврати, Старице небого.

(према Пантић 1964: 57)

${ }^{18}$ Њени стихови који се односе на биље гласе овако:

Ђевојке су ружу брале.

Ододољено,

Одумиљено,

Од струк босиља,

Од невесиља,

Од калопера,

Од тратора гранатога,

Од невена окатога,

Од ружице румените.

(Караџић 1841: бр. 333)

${ }^{19}$ Сегмент игре с певањем који се односи на тратор код Врчевића гласи овако:

Убра Ајка одољена,

Пуну киту умиљена,

И руковет каранфила,

И невена окатога,

И тратора гранатога,

И ружице румените.

У вези с овим види и расправу Вељка Радојевића (1896: 121-127).

${ }^{20}$ Тратор, стратор се иначе јавља у песмама о чудесном орачу; присутан је у песмама с мотивом девојка прави лежај момку од биља. Тратором се у одговарајућем обреду атрибура стари сват. Спорадично, тратор се помиње у неколиким лирским песмама других мотивских кругова.
} 
1995: 131). ${ }^{21}$ Босиљком се гата о удаји, млада гледа младожењу кроз босиљак, у Призрену кад прстенџије улазе у девојачку кућу она треба да их кришом погледа кроз венац од босиљка; а кад сватови улазе у младино двориште, она је, такође на Косову, младожењу гледала кроз босиљак, говорећи: „Ја те гледах једним оком и нагледах те се, а ти мене са оба не можеш" (према Чајкановић 1994а: 40-41). Аналогна магијска радња обављана је и у Темнићу, где је девојка гледала момка кроз венац од босиљка који је сама исплела (према Чајкановић 1994а: 40). Уз тратор и босиљак у венцу се јавља невен (Calendula officinalis), који такође има важну улогу у љубавној магији и сватовској обредности, а којег млада доноси мужу да би венуо за њом, а и уплитао се у сватовски венац (Чајкановић 1994а: 154; Гура 1995: 322). У песми из околине Бољевца - за коју се такође каже да је извођена док девојке у петак у зору плету мали венац - поред босиљка, налазе се љиљак (Syringa vulgaris) и смиље (Helichrysum arenarium), у стиховима:

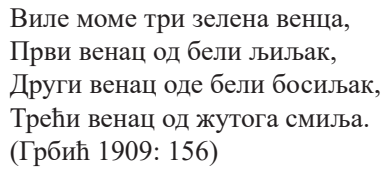

И ове биљке такође су присутне у одговарајућим ритуалима. Смиља је увек било у сватовском венцу (в. Гура 1995: 322); млада је кроз венац од смиља и босиљка гледала младожењу, босиљак и смиље су у капи смиљевцу (према Чајкановић 1994а: 37 и 189). А и јоргованом (љиљак) су се накад китили сватови (в. Чајкановић 1994а: 109). Веровања везана за големо цвеће, висока кадифа (Tagetes erectus), међутим, нису забележена у класичној етнографској литератури, али је она документовано коришћена у свадбеним обичајима у Тимоку, где се стављала у китку, на буклију, венац (Станојевић 1929: 36, 42-43, 46).

Испитивани ритуал се, дакле, у најкраћем састоји од поступака и песама које су извођене у петак или суботу, рано ујутро пре свадбе, обележавајући почетак и крај као и ток плетења, на дрвљанику, код момкове куће, где су девојке виле венац, а затим на прагу где је седела свекрва, где би јој стављали на главу сито у којем је била кошуља (коју је девојка даровала будућем мужу) и извијени венац, а сватови га, улазећи у момкову кућу, даривали. Плетење венца на дрвљанику и прагу (прављен је и венац за капију/врата), на којима су иначе вршени и други свадбени ритуали, мотивисано је семантиком границе која је инхерентна овим локусима (в. ван Генеп 2005: 24-26, 68-72; Усачова 2009: 141; Плотњикова 2009: 173 -175), и у вези је с преласком из једног у други друштвени статус, односно, све је повезано системом граничних хронотопа који семантизују про-

${ }^{21}$ „Как универсальное охранительное и отгонное средство базилик использовался для украшения людей, животных, построек, предметов домашнего обихода, пищи и т. п. Для этого изготавливали венки, букетики, гирлянды, часто с другими растениями (...) или брали отдельные веточки, цветы” (Усачова 1995: 131). О утемељености босиљка у хришћанској религији где је апотропеј прве врсте, али и медијатор између људи и божанске силе (в. Ренкас 2016: 41). 
мену. У плетењу венца и око њега учествовали су различити чланови заједнице, који у обредно-обичајној пракси око склапања брака имају важну улогу, пре свега девојке. Јер тек оплемењен њиховим додиром, али и с младожењом, свекрвом и сватовима, венац је био спреман да га млада понесе на венчање. И песме које се том приликом изводе у истој су функцији, оне такође подржавају, коментаришу и објашњавају радње које су у функцији повезивања. Тако све заједно показује како различите радње и вербализације могу бити, и јесу, реплика обредне стварности и у односу су корелације, што сведочи и присуство одређених биљака у његовој акционалној и вербалној димензији доприносећи симболичкој вишезначности обреда.

Плетење сватовског венца, дакле, као и сви други ритуали, представља својеврстан културолошки текст који се испољава кроз одређене акције и вербализације у одређеном време-простору у којем их обављају учесници обреда. ${ }^{22}$ И све је ту повезано и семиотички маркирано образујући својеврсну „реалност” (Гура 2006: 268) која је у функцији стварања нових односа и веза у заједници, што је неопходно имати на уму како би се разумела природа комуникације која се ту остварује. И зато су у односу на своје природне прототипове сви ти елементи различити, односно задобијају симболичка значења (в. о томе Толстој 1995: 141-143).

Неопходно је, такође, поменути да се у овом сегменту свадбе, односно обреду вијења венца и песмама аналогне садржине у Тимоку - међусобно се објашњавајући и допуњавајући - сучељавају различити варијантни записи, који рефлектују динамику живота људи тога краја, што се прати у записима на терену и у суседним областима у периоду од око сто година (о чему данас нема ни трага). Изоловани песнички мотив девојка плете венац и намењује га неком пак евидентиран је још у песмама на народну дубровачко-далматинског приморја, насталим управо под утицајем усмене песничке традиције, а затим је присутан у записима Вука Караџића (први пут 1824) и доцније, што шири поменуте координате и потврђује постојање испитиване песничке традиције и обредне праксе као кохезионог језгра на српском културном простору у периоду од неколико векова, о чему данас сведоче писани извори и само понеки траг сећања.

${ }^{22}$ Различите манифестације обреда Никита Толстој, будући да су шифроване, назива кодовима. По њему акционални код подразумева редослед одређених радњи, у којем се користе различити предмети који имају симболичка својства, вербални код обухвата пропратне текстове који се том приликом изводе, извођачи припадају персоналном коду, док се простор у којем се радње одржавају везује за локативни код, време одржавања ритуала везује се за темпорални код, музички код је певање, или интрументална пратња, док ликовни код подразумева различите визуализације предмета и учесника (Толстој 1995: 141). 


\section{Прилог}

1

Вила Јана, драго, зелен венац

Од босиљћа, драго, гранатога,

И од смиља, драго, ћитатога,

Од стратора, драго, крстатога.

Ем га вила, ем му говорила:

„Виј се венче, драго, завијај се,

Да те носи, драго, Д... јунак,

Д... јунак, драго, и добра девојка

(Станојевић [1896]: бр. 121)

2

Виле моме три зелена венца,

Први венац од бели љиљак,

Други венац од бели босиљак,

Трећи венац од жутога смиља.

(Грбић 1909: 156)

\section{3}

Вила Јана, драго, зелен венац,

Вила га је, па му говорила:

„Виј се, венче, драго, довијај се,

Да те носи, драго, Давњан јунак,

Давњан јунак, драго, и добра девојћа."

(Станојевић 1929: 46)

3

Виле моме три смиљева венца,

Први венац од белог босиљка,

Други венац од жутога смиља,

Трећи венац од големог цвећа:

„Виј се, венче, драгом се довијај,

Ти ћеш ићи драгом на далеко,

На далеко, драгом по девојку,

Добрим коњем драгом за два дана,

Лошим коњем драгом за четири.

(Матић 1963: 71)

4

Виле моме драгу зелен венац,

Од стратора, драгу, крстатога,

Од невена, драгу, шестопера

(Рајковић Кожељац 1963: 73)

5

Виле моме драгу зелен венац,

Ем га виле, ем му говориле:

„Виј се венче, виј се, савијај се

Од стратора, драгу, крстатога,

Од невена, драгу, шестопера".

(Рајковић Кожељац 1972: бр. 32) 
6

Виле моме три залена венца,

Први венац од бели босиљак,

Други венац од жутога смиља,

Трећи венац од големо цвеће.

Ви се венче, драго ле,

За девојку, драго ле,

С добри коњи, драго ле,

За два дана, драго ле,

А по лоши, драго ле,

За четири, драго ле.

(Рајковић Кожељац 1978: бр. 164)

7

Ви се, венче, ми те довијамо,

Ти ћеш, венче, код кумов д' идеш,

Од кумове, венче, до старојку,

Од старојку, венче, до девојку.

(Васић [1996/7]1999: 268, Врбица, Ново Корито)

\section{8}

Виле моме три венца зелена,

Први венац од големо цвеће,

Други ванац од жутога цвећа.

Што је венац од жутога цвећа,

То је венац за милога кума,

Што је венац од белог босиљка,

То је венац за старога свата.

Што је венац од жутога смиља,

То је венац за младу и младог.

(Васић [1996/7] 1999: 269: Васиљ)

9

Вила Јана, драго, зелен венац,

Па извила два зелена венца.

Један момку, један на девојку.

(Савка Савић [1997], Ошљане)

10

Вила Јана драгу зелен венац,

Па извила три зелени венца:

Један венац за кумово здравље,

Други вила за свекрово здравље,

Трећи вила младима за здравље.

(Роса Николић [1997], Ошљане)

11

Виј се, венче, драго, завијај се,

Од стратора крстатога,

Од босиљка, драго, китестога.

(И ваљда од невена шестопера, додаје кћерка)

(Анка Цветковић [1997], Кожељ, мало певала) 


\section{ЛИТЕРАТУРА}

Васић 1999: О. Васић, Ви се венче, ми те довијамо, Етнокултуролошки зборник за проучавање културе источне Србије и суседних области, књ. V, Сврљиг, 267-270.

Васиљевић 1960: М. Васиљевић, Народне мелодије лесковачког краја, Београд: САНУ, Музиколошки институт.

Врчевић 1889: В. Врчевић, Српске народне игре које се забаве ради по састанцима играју: Књига II, 2, Дубровник: Наклада књижаре Драгутина Претнера, 41-43.

Ван Генеп 2005: Ј. ван Генеп, Обреди прелаза, прев. Ј. Лома, Београд: СКЗ.

Грбић 1909: С. Грбић, Српски народни обичаји из Среза Бољевачког, Српски етнографски зборник, књ. XIV, Београд: САНУ.

Гура 1995: А. Гура, Венок свадебный, Славянские древности, Этнолингвистический словарь в пяти томах, ур. Н. И. Толстого, т. 1, Москва: Институт славноведения РАН, 321-325.

Гура 2006: А. Гура, Соотношение и взаимодействие акционального и вербального кодов свадебного обряда, Славянский и балканский фольклор. Москва: Индрик: 268-279.

Детелић 1992: М. Детелић, Митски простор и епика, Београд: Српска академија наука и уметности.

Димитријевић 1987: С. Димитријевић, Народне песме лесковачког краја, Свеска 1, Лесковац: Народни музеј.

Ђорђевић 1953: Т. Ђорђевић, Вештица и вила у нашем народном веровању и предању, Српски етнографски зборник, LXI, Београд: Српска академија наука и уметности.

Ђорђевић 1958: Д. Ђорђевић, Живот и обичаји народни у Лесковачкој Морави, Српски етнографски зборник, књ. LXX, Београд: Српска академија наука и уметности.

Жугић 2013: Р. Жугић, Микротопонимија горњег слива Јабланице (семантичко-творбени аспект), Београд: Институт за српски језик САНУ.

Златановић 1994: М. Златановић, Народне песме и басме јужне Србије, Београд: Српска академија наука и уметности.

Јакобсон 1966: R. Jakobson, Lingvisitka i poetika, prev. D. Pervaz, T. Bekić, V. Vuletić, S. Marić, R. Bugarski, Beograd: Nolit.

Карановић 2021: 3. Карановић, Збирајте се моме и девојке: српски свадбени обичаји везани за зборњак - теренска истраживања у Белом Тимоку, Philologia mediana, 13: 543-558.

Караџић 1841: В. Ст. Караџић Српске народне пјесме, I, Беч: Штампарија Јерманскога манастира.

Караџић 1852: Српски рјечник истумачен њемачким и латинскијем ријечима. Беч: Штампарија Јерменскога манастира. 
Крњевић 1986: H. Krnjević, Lirski istočnici Iz istorije i poetike lirske narodne poezije, Beograd, BlGZ; Priština, Jedinstvo.

Лајшић 2009: S. Lajšić, Pjesme „na narodnu” u Zborniku Nikše Ranjine i u lirici Frana Krste Frankopana, RAD 502: 171-190.

Лорд 1990: А. В. Lord Pеvač priča I i II, prev. S. Glišić, Beograd: Idea.

Маљцев 1989: Г. И. Мальцев, Традиционалньие формуль русской народной необредовой лирики. Ленинград: Наука.

Манић Форски 1974: Д. Манић Форски, Антологија лужничких народних песама, Пирот, Бабушница: „Графика”.

Матић 1963: Р. Матић, Свадбене народне песме које се певају испод Ртња у долини Црне Реке, Развитак бр. 4-5, Зејечар: 71-72.

Милићевић 1876: М. Ђ. Милићевић, Кнежевина Србија, Београд: Државна штампарија.

Недић 1967: В. Недић, Зборник Никше Рањине и усмено песништво, Анали Филолошког факултета, 7, Београд: 31-41.

Пантић 1964: М. Пантић, Народне песма у записима XV-XVIII века, Београд: Просвета.

Петровић 1998: П. Ж. Петровић, Венац, Српски митолошки речник. ур. Ш. Кулишић, П. Петровић, Н. Пантелић, Београд: Етнолошки институт САНУ, Интерпринт.

Плотњикова 2009: А. А. Плотникова: Порог, Славянские древности. Этнолингвистический словарь в пяти томах: ур., Н. И. Толстого, т. 4. Москва: Институт славноведения РАН 173-178.

Радојевић 1896: В. Радојевић, Српске народне пјесме као скитачице, Луча, Цетиње: 121-127.

Рајковић Кожељац 1963: Љ. Рајковић Кожељац, Свадбене песме из Кожеља, Развитак, Зајечар бр. 4-5: 73.

Рајковић Кожељац 1972: Љ. Рајковић Кожељац, Двори самотворни (народне умотворине из средњег Тимока, Зајечар: „Тимок”.

Рајковић Кожељац 1978: Љ. Рајковић Кожељац, Здраваи мирииљавац, народне песме и бајалиие из Тимочке крајине, Зајечар: Графичко-издавачко предузеће ,Зајечар".

Ренкас 2016: J. Ренкас, Хришћанска симболика босиљка у контексту теорије културе меморија религијских група, Гора Љиљанова, биљни свет у традициионалној култури Срба, ур. 3. Карановић и Ј. Дражић, Београд: Удружење фолклориста Србије, Универзитетска библиотека „Светозар Марковић” Београд: 41-57.

Решетар 1937: M. Rešetar, Pjesme Šiška Menčetića i Gore Držića, i ostale pjesme Rańinina Zbornika, Stari pisci hrvatski, knjiga II, drugo, sasvim preudešeno izdańe, Zagreb: JAZU.

Симоновић 1959: Д. Симоновић, Ботанички речник имена биљака, Београд: САНУ. 
Станковић 2009: М. Станковић, Лика које више нема, ми се нас морамо сјећати, Београд: Удружење Срба из Храватске.

Станојевић 1896 (ркп): М. Станојевић, Народне песме из источних крајева, поглавито из Гор. Тимока и Пирота и његове околине, РКП САНУ, бр. 27.

Станојевић 1929: М. Станојевић, Свадбени обичаји у Тимоку, Зборник прилога за познавање Тимочке крајине, 1, Зајечар: 23-79.

Станојевић 1930: М. Станојевић, Народна песма у Средњем Тимоку, Зборник прилога за познавање Тимочке крајине, Зајечар, 2, 59-70.

Станојевић 1937: М. Станојевић, Свадбени обичаји, Зборник прилога за познавање Тимочке крајине, 4, Зајечар: 83-93.

Тарнер 1986: В. Тарнер, Варијације на тему лиминалности, Градина X, Ниш: 40-56.

Толстој 1995: Н.Толстој, Секундарна функција обредног симбола, Језик словенске културе, Ниш: Просвета: 141-160.

Усачова 1995: В. Усачёва, Базилик свадебный, Славянские древности: Этнолингвистический словарь в 5-ти тm. T. 1 ред. Н. И. Толстого. Москва: Институт славяноведения РАН: 131-132.

Усачова 2009: В. Усачёва, Полено Славянские древности. Этнолингвистический словарь в пяти томах, ред., т. 4. Н. И. Толстого, Москва: Институт славноведения РАН: 139-141.

Чајкановић 1935: В. Чајкановић, Босиљак, Гласник етногрфског музеја у Београду, бр. 10, Београд: 3-10.

Чајкановић 1994а: В. Чајкановић, Речник српских народних веровања о биљкама, Сабрана дела, књ. IV, прир. В. Ђурић, Београд: СКЗ, БИГЗ, Просвета, Партенон.

Чајкановић 1994б: В. Чајкановић, Религија и култ дрвета и биљака, Cтара српска религија и митологија, у Сабрана дела, књ. V. прир. В. Ђурић, Београд: СКЗ, БИГЗ, Просвета, Партенон: 169-182.

Шулек 1879: B. Šulek, Jugoslavenski imenik bilja, Zagreb, JAZU. 
Зоја С. Карановић

\section{СВАДЕБНЫЙ ВЕНОК И ПЕСНЯ В ОБРЯДНОЙ ПРАКТИКЕ В СЕЛАХ НА ПОБЕРЕЖЬЕ Р. БЕЛИ ТИМОК (забытая традиция)}

Резюме

В статье исследуется сегмент свадебных обычаев, связанных с ритуальными и магическими действиями и песнями которые поются при заворачивании венка. Исследование создано на основе материалов собранных автором в 1997. и 1998. в деревнях вокруг реки Бели Тимок (юго-восточная Сербия), также на основе более ранних записей в соседних районах. На основании этого материала построена идеально-типовая (ре)конструкция упомянутого ритуала, который совершался утром перед свадьбой, в доме жениха, на том месте где хранились дрова. Там девушки плели венок (невесты на свадьбу) и пели разные песни. Когда девушки заканчивали заворачивать венок, они клали его в решето, содержащий рубашку которую девушка прислала жениху. Сито с венком и рубаху девушки потом бы надели на голову свекрве, сидевшей на пороге; а приходившие на свадьбу гости бросали монету в сито „давая на венок”. Так, в В заданной обрядовой среде анализируются песни и исследуется их связь с аналогичными проявлениями ритуалов, а также исследуются их связи, значения и функции в исследуемой области и в сербской сельской культуре в целом. Их анализ показывает что плетение свадебного венка, как и все другие ритуалы, представляет собой своего рода культурный текст, который проявляется через определенные действия и вербализацию, происходящие в установленное время и в определенное пространстве, в котором они выполняются участниками церемонии. А все связано и семиотически обозначено, образуя параллельную реальность, выполняющую функцию создания новых отношений и связей в сообществе, что необходимо иметь в виду, чтобы понять природу общения, которое происходит при традиционом вступлении в брак.

Ключевые слова: Сербская традиционная культура, полевая работа, деревни вокруг речки Бели Тимок (юго-восточная Сербия), свадебный ритуал, венок, песня. 